\title{
Redescription of Cryptotbele alluaudi Simon, 1893 (Aranei: Cryptothelidae)
}

\section{Переописание Cryptotbele alluaudi Simon, 1893 (Aranei: Cryptothelidae)}

\author{
Yuri M. Marusik ${ }^{1,2}$, Mikhail M. Omelko ${ }^{3,4}$ \\ Ю.М. Марусик ${ }^{1,2}$, М.М. Омелько
}

\footnotetext{
${ }^{1}$ Institute for Biological Problems of the North, RAS, Portovaya Str. 18, Magadan 685000, Russia.

${ }^{2}$ Zoological Museum, University of Turku, FI-20014 Turku, Finland.

${ }^{3}$ Gornotaezhnaya Station FEB RAS, Gornotaezhnoe Vil., Ussuriyski Dist., Primorski krai 692533 Russia.

${ }^{4}$ Far Eastern Federal University, Sukhanova, 8, Vladivostok 690950 Russia.

${ }^{1}$ Институт Биологических Проблем Севера ДВО РАН, ул. Портовая 18, Магадан 685000, Россия.

2 Зоологический музей, университет Турку, FI-20014 Турку, Финляндия.

${ }^{3}$ Горнотаёжная станция ДВО РАН, с. Горнотаёжное, Уссурийский район, Приморский край 692533 Россия.

${ }^{4}$ Дальневосточный Федеральный университет, Суханова 8, Владивосток 690950 Россия.
}

KEYWORDS: Seychelles, Zodariidae, Cryptothelidae.

КЛЮЧЕВЫЕ СЛОВА: Seychelles, Zodariidae, Cryptothelidae.

ABSTRACT. Endemic of Seychelles Islands and westernmost species of Cryptothele L. Koch, 1872, C. alluaudi Simon, 1893, is redescribed on the basis of both sexes.

РЕЗЮМЕ. Эндемик Сейшельских островов и самый западный вид рода Cryptothele L. Koch, 1872, C. alluaudi Simon, 1893 переописан по самцу и самке.

\section{Introduction}

Cryptothele was established by L. Koch for the new species Cryptothele verrucosa L. Koch, 1872, occurring on Samoa and Fiji [L. Koch, 1872]. Since the original description in 1872, this species was never redescribed. For a long time the genus was considered part of the Zodariidae [Simon, 1893]. Family status was given to it by Davies [1985], but Wunderlich [2004] reduced its status back to subfamily. We consider this group as separate family.

Up to now only 10 species (counting two subspecies) belonging to Cryptothele are known [Platnick, 2012]. All species are known from the Indian Ocean and the western part of the Pacific Ocean (Fig. 10). All species, except for $C$. sundaica amplior Kulczyński, 1911, and C. sundaica javana Kulczyński, 1911, were described at the end of $19^{\text {th }}$ century. Five of ten species and subspecies are known by females only. One species, C. cristata Simon, 1884, with an unknown type locality is known by a juvenile, and the description of C. collina Pocock, 1901, is based on specimens for which there is no indication of sex or stage [Platnick, 2012]. Only three species are known by both sexes. In the $20^{\text {th }}$ century only two species were the subjects of redescriptions C. alluaudi Simon, 1893 [Benoit, 1978] and C. sundaica javana (Roewer, 1938). It seems that it is one of worst studied spider groups at the family level.

Although C. alluaudi is described from the remote Seychelles, it is the best studied species of the whole group. Nevertheless, many features of the palp, epigyne, somatic morphology, and even habitus of the male, were never illustrated for this and other species. The purpose of this paper is to provide an illustrated description of $C$. alluaudi and to present a map showing the distribution of all Cryptothele species.

\section{Material and methods}

Specimens were photographed using an Olympus Camedia E-520 camera attached to an Olympus SZX16 stereomicroscope. The images were montaged using "CombineZP" image stacking software. Photographs were taken in dishes of different sizes with paraffin in the bottom. Different sized holes were made in the paraffin to keep the specimens in the correct position. All material studied are from the Zoological Museum, University of Turku.

\section{Cryptothele alluaudi Simon, 1893} Figs 1-9.

C. a. Simon, 1893: $205\left(\mathrm{D}_{+}^{\circ}\right)$.

c. a.: Benoit, 1978: 694, f. 2, 3A-D ( $\left.{ }^{7}+\right)$.

C. a.: Wunderlich, 2004: f. 3-4 ( $\sigma^{7}$, copy of the Benoit's figures).

C. a.: Saaristo, 2010: 64. f. 7.1-4 (o $)$.

MATERIAL EXAMINED: SEYCHELLES: Conception, pitfall, 1 juv. (MZT AA 1.543), 27.02.2000. Cousine, 1 juv. (MZT AA 0.471), 25.01.1999 (M. Saaristo). Felicite, 2 juv. (MZT AA 2.279 and 2.293), 23-24.03.2002 (J. Gerlach). Mahé, 1juv. (MZT 

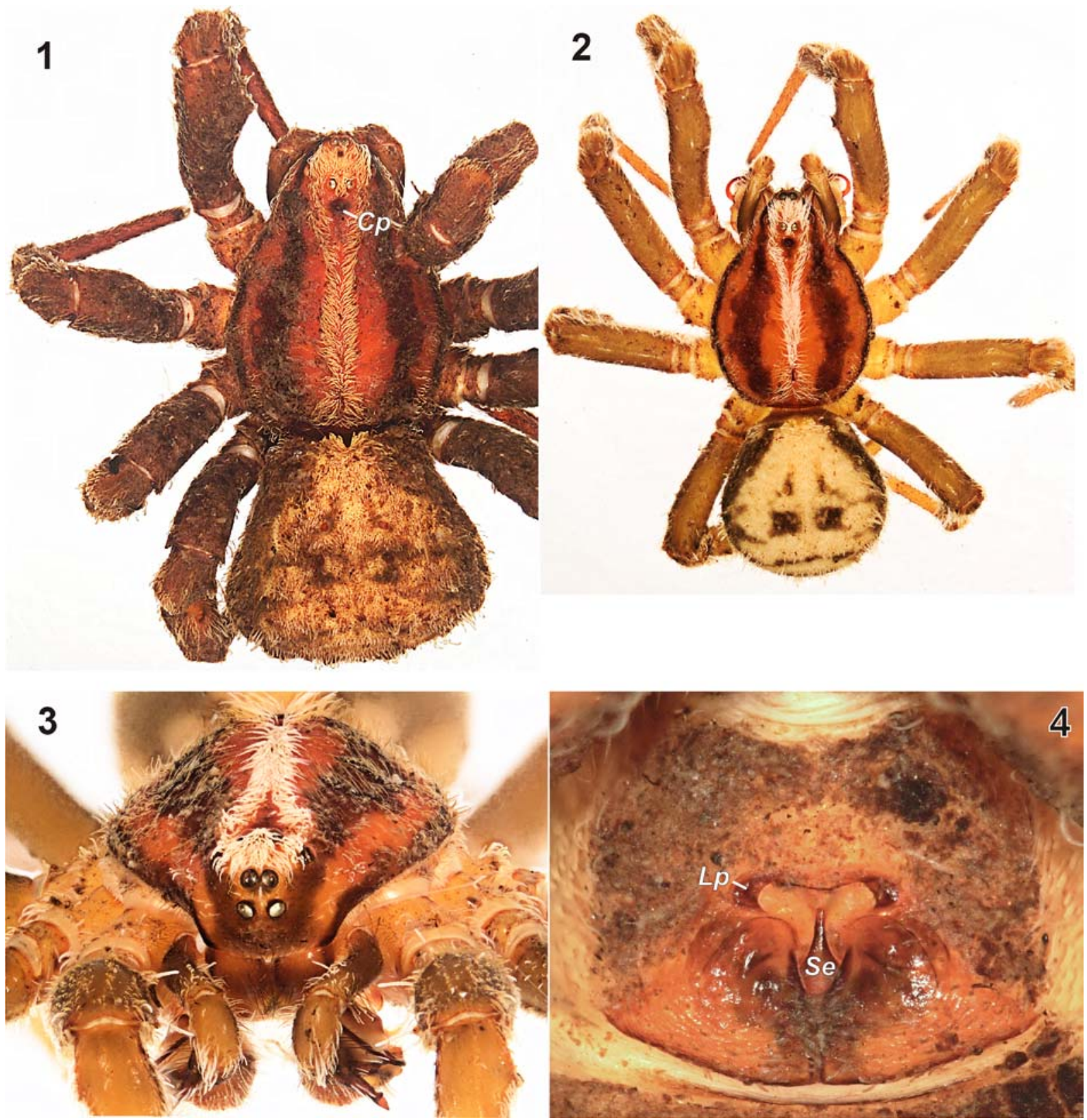

Figs 1-4. General appearance and epigyne of Cryptothele alluaudi. 1 - female, dorsal; 2-3 - male, dorsal and frontal; 4 - epigyne, ventral.

Abbreviations: $C p$ - cephalic pit, $L p$ - lateral pocket, $S e$ - septum.

Рис. 1-4. Внешний вид и эпигина Cryptothele alluaudi. 1 - самка, дорсально; 2-3 - самец, дорсально и фронтально; $4-$ эпигина, вентрально.

Сокращения: $C p$ - ямка головогруди, $L p$ - латеральные карманы, $S e$ - септум.

AA 0.472), Jan. 1999 (M. Saaristo, P. Matyot \& M. Kirkpatrick); 1 +1 juv. (MZT AA 0.473) (J. Gerlach); 1 (MZT AA 0.923), Jan. 1999 (M. Saaristo, P. Matyot \& M. Kirkpatrick). North, 2 우 (MZT AA 1.338), 30.07.2000 (J. Gerlach). Silhouette, La Passe, $\sigma^{7}, 1$ juv. (MZT AA 0.465), 17.01.1999 (M. Saaristo \& J. Gerlach); $1 \mathrm{O}^{7}$ (MZT AA 0.466), 13.01.1999 (M. Saaristo); 1 \&, 3 juv. (MZT AA 0.467), 24.01.1999 (M. Saaristo \& J. Gerlach); Anse Lascars, 1 juv. (MZT AA 0.468), 12.01.1999 (M. Saaristo); Belle Vue, 1 juv. (MZT AA 0.469), 18.01.1999 (M. Saaristo \& J. Gerlach); Anse Cimitaire, $1 \mathrm{O}^{\top}$ (MZT AA 0.470), 18.01.1999 (M. Saaristo); Mon
Plaisir-Mt. Dauban, Pandanus seychellarum crown, 1 ㅇ (MZT AA 1.334), 11.08.2000 (J. Gerlach); Jardin Marron, 1 O (MZT AA 1.335), 11.08.2000 (J. Gerlach); Jardin Marron (Coco de Mer), litter, $1 \mathrm{O}^{\mathrm{T}}$, 9juv. (MZT AA 1.336), 5.07.2000 (J. Gerlach); Mon Plaisir, Litter, 2 juv. (MZT AA 1.337), 8.07.2000 (J. Gerlach); Jardin Marron, Malaise trap, $10^{7}, 1$ ㅇ (MZT AA 2.256), Sept. 2000 - Aug. 2001 (R. \& J. Gerlach); La Passe, leaf litter, $10^{7}$ (MZT AA 2.319), 12.07.2001 (J. Gerlach). St. Anne, 7 juv. (MZT AA 2.210), 10.12.2001 (J. Gerlach). 

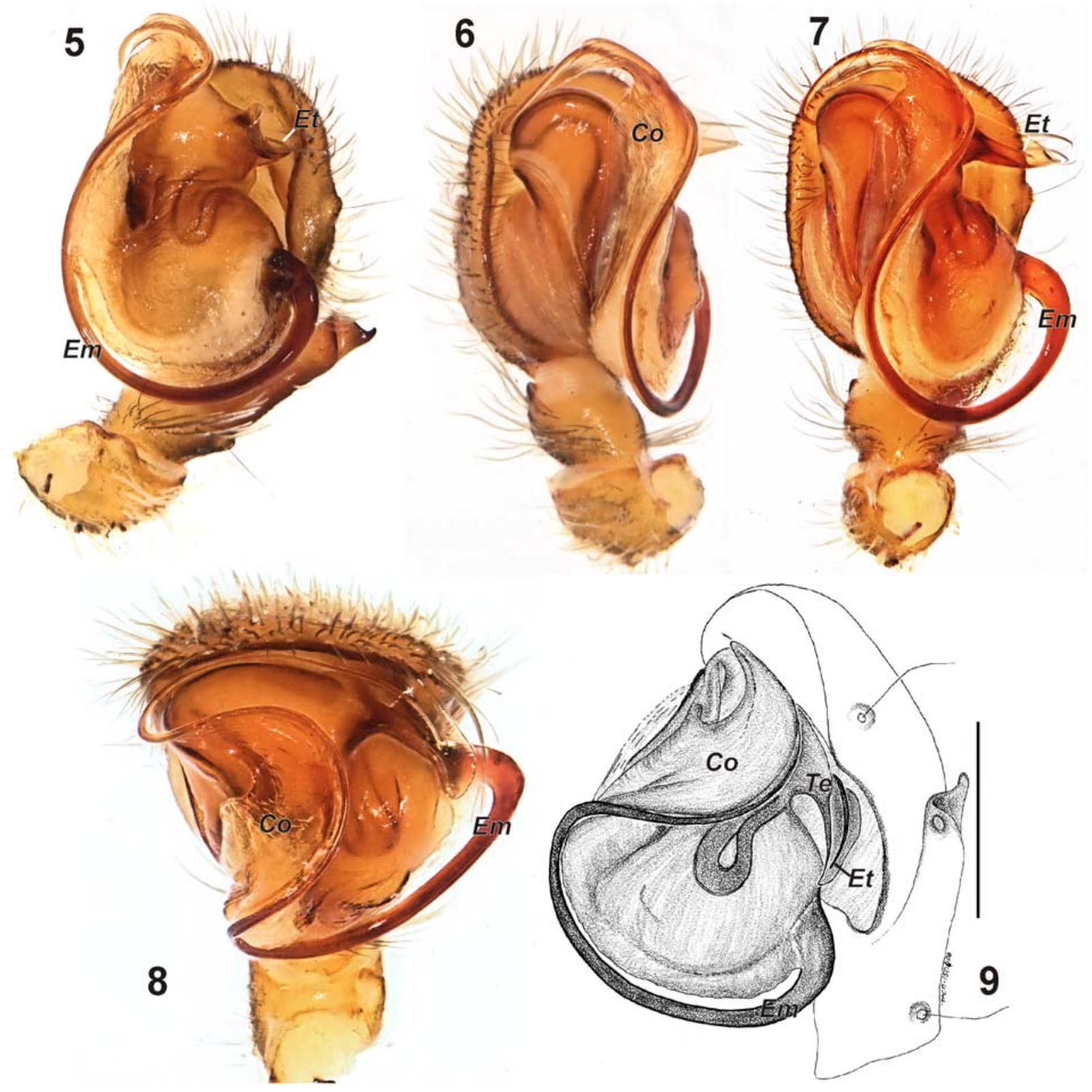

Figs 5-9. Male palp Cryptothele alluaudi. 5 - retrolateral; 6 - prolateral; 7 - ventral; 8 - from above; 9 - retrolateral - from above; 9 - after Saaristo [2010].

Abbreviations: $\mathrm{Co}$ - conductor, $E m$ - embolus, $E t$ - embolic tip, $T e$ - tegular extension.

Рис. 5-9. Пальпа самца Cryptothele alluaudi. 5 - ретролатерально; 6 - пролатерально; 7 - вентрально; 8 - сверху; 9 ретролатерально — сверху; 9 - по Saaristo [2010].

Сокращения: $C o$ - кондуктор, $E m$ - эмболюс, $E t$ - кончик эмболюса, $T e$ — вырост тегулюма.

DESCRIPTION. Males 6.5-7.2 mm long; females 10.0-11.5 mm long. General colouration brown. Male brighter in colouration with darker bands. Carapace with white median band formed by white hairs; median part brown; lateral band dark brown, they starts on clypeus; dark band wider than sublateral brown stripes; margins with dark brown stripes. Cephalic part with distinct pit $(C p)$ behind eyes. Female carapace covered with soil particles. Abdomen lighter than carapace, without distinct pattern in female and with distinct pattern in male. Sides of abdomen darker than dorsum. Cephalic area with pit behind posterior median eyes. Male palp as in Figs 5-9, with two trichobothria on tibia and cymbium arising from protruding bases; tibia 


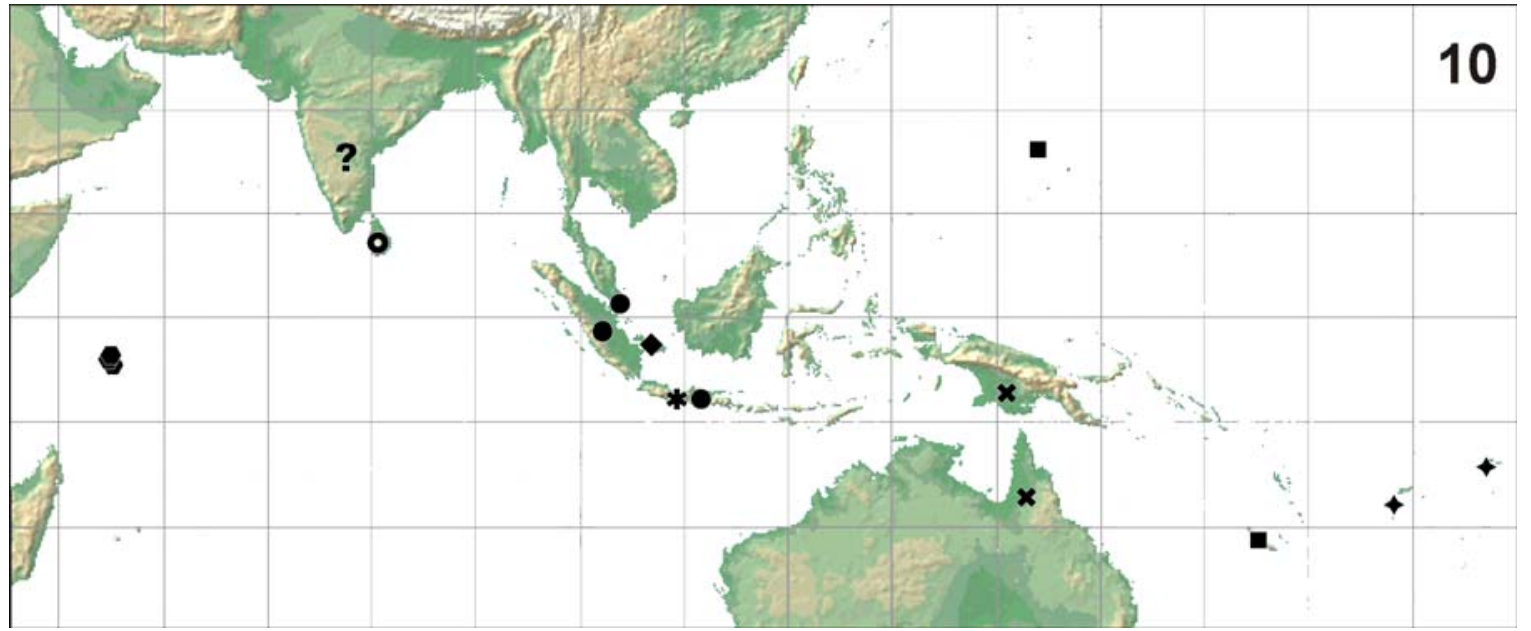

Fig 10. Distribution of Cryptothele species.

- _ alluaudi; ? - collina; $\mathbf{O}$ - ceylonica; $\mathbf{-}$ - sundaica;

marchei; - verrucosa. Type locality of C. cristata is unknown.

Рис. 10. Распространение видов рода Cryptothele.

- - alluaudi; ? - collina; $\mathbf{0}$ - ceylonica; $\bigcirc$ - sundaica;

marchei; $\downarrow$-verrucosa. Типовое местообитание C. cristata неизвестно.

with long retrolateral apophysis; cymbium oval; median (tegular) apophysis absent, tegulum with retrolateral extension ( $\mathrm{Te}$ ) serving as conductor for the tip of embolus $(E t)$; conductor $(C o)$ distinct; embolus $(E m)$ long, starts on the retrolateral side, made several turns (loops) in three dimensions. Epigyne as in Fig. 4, fovea triangle, with septum $(\mathrm{Se})$ and two lateral pockets $(L p)$.

DISTRIBUTION. It is a species endemic to Seychelles. So far it is recorded from nine large islands: Conception, Cousine, Felicite, Fregate, La Digue, Mahé, Praslin, Silhouette and St. Anne and several smaller [Simon, 1893, 1898; Hirst, 1911; Benoit, 1978; Saaristo, 1999; Saaristo \& Hill, 2002].

ACKNOWLEDGEMENTS. We wish to thank Seppo Koponen who arranged our stay in Turku and allowed the use of local facilities (digital camera attached to microscope). English of the final draft was kindly checked by Justin Gerlach and Robin Leech. This work was supported in part by the Russian Foundation for Basic Research (grants \#\# 11-0401716 and 12-04-01548).

\section{References}

Davies V.T. 1985. Araneomorphae (in part) // Zoological Catalogue of Australia. Vol.3. P.49-125.

Benoit P.L.G. 1978. Contributions à l'étude de la faune terrestre des íles granitiques de l'archipel des Séchelles (Mission P.L.G.
Benoit \& J.J. van Mol 1972). Clubionidae, Ctenidae et Pisauridae (Araneae) // Revue de Zoologie africaine. T.92. P.940946.

Hirst A.S. 1911. The Araneae, Opiliones and Pseudoscorpiones. Percy Sladen Trust Expedition to the Indian Ocean in 1905 under the leadership of Mr. J. Stanley Gardiner // Transactions of the Linnean Society, London, Zoology. Vol.14. P.379-395.

Koch L. 1872. Die Arachniden Australiens. Nürnberg. Bd.1. S.105368.

Platnick N.I. 2012. The World Spider Catalog. Version 12.5. American Museum of Natural History, New York, online at http://research.amnh.org/iz/spiders/catalog/

Saaristo M.I. 1999. An arachnological excursion to the granitic Seychelles, 1-26th January, 1999. Arachnid species lists for Silhouette, Cousine and Mahé // Phelsuma. Vol.7A. P.1-12.

Saaristo M.I. 2010. Araneae // Gerlach J., Marusik Y.M. (eds.). Arachnida and Myriapoda of the Seychelles islands. Manchester: Siri Scientific Press. P.8-306.

Saaristo M.I., Hill M.J. 2002. Spiders (Arachnida, Araneae) collected by BirdLife GEF Island Assessment Project 1999-2000 // Atoll Research Bulletin. Vol.495(1). P.221-231.

Simon E. 1893. Arachnides. In Mission scientifique de M. Ch. Alluaud aux îles Seychelles (mars, avril, mai 1892) // Bulletin de la Societe Zoologique de France. T.18. P.204-211.

Simon E. 1898. Etudes arachnologiques. 29e Mémoire. XLVI Araichnides recueillis en par M. le Dr. A. Brauer (de l'Université de Marburg) aus Iles Séychelles // Annales de la Societe Entomologique de France. T.66. P.370-385.

Wunderlich J. 2004. The fossil spiders (Araneae) of the family Zodariidae in Baltic amber, with remarks on their subfamilies including the Cryptothelinae and the Homalonychinae // Beiträge zur Araneologie. Vol.3. P.1578-1611.

Responsible editor K.G. Mikhailov 